Lepr Rev (1991) 62, 150-154

\title{
Treatment of recent facial nerve damage with lagophthalmos, using a semistandardized steroid regimen
}

\author{
K UDAYA KIRAN*, MARGREET HOGEWEG $† \&$ \\ SUJAI SUNEETHA \\ Dhoolpet Leprosy Research Centre, Hyderabad 500 006, India; \\ *Hyderabad Project, Lepra India Society, 10-4-771-/B, Sriram \\ Nagar Colony, Masab Tank, Hyderabad 500 028, India; †Depart- \\ ment of Ophthalmology, Erasmus University, Rotterdam, The \\ Netherlands; $\ddagger$ Schieffelin Leprosy Research \& Training Centre, \\ Karigiri, S. India
}

\section{Accepted for publication 14 January 1991}

Summary Twenty-seven patients with borderline leprosy and facial nerve damage of $\leqslant 6$ months duration ( 36 eyes) were treated with a semistandardized regimen of steroids (the average starting dose was $25-30 \mathrm{mg}$, duration 5-6 months) on an outpatient basis. Red and raised reactive patches were usually present in the upper malar area or around the eye(s) in patients with recent lagophthalmos.

The lid gap was measured in millimetres during gentle and strong closure. After completion of the steroid course $75 \%$ of the eyes had complete closure or only a slight gap of $\leqslant 2 \mathrm{~mm}$ on gentle closure.

Steroids were found to be beneficial and safe, in the dosage that we prescribed.

\section{Introduction}

It is a common experience that a patient will present himself for treatment because of recent nerve damage, often of only a few months duration. In the case of facial nerve damage the patient presents himself with lagophthalmos. The prospect of improvement is good, if effective treatment for nerve damage is instituted promptly. ${ }^{1,2}$

In patients with borderline leprosy, nerve damage is caused by a cell-mediated immune response to antigens of Mycobacterium leprae, and most patients with recent facial nerve damage show signs of actual Type 1 reaction and have a 'significant' facial patch around the eye or malar region which is red and raised. ${ }^{3}$

This paper reports the results of outpatient treatment of recent facial nerve damage with lagophthalmos using a semistandardized prednisolone regimen. 


\section{Patients and methods}

The study includes 27 borderline leprosy patients registered between 1982 to 1988 at the Dhoolpet Leprosy Research Centre with recent facial nerve damage of less than 6 months duration. These patients had completed their prescribed course of steroids for nerve damage. This treatment is on an outpatient basis with patients attending usually once a month. About half of the patients had received some previous antileprosy treatment before registration, the others were untreated.

\section{INITIAL ASSESSMENT}

This included clinical examination of the skin and facial lesions and palpation of nerves. Patients were classified according to the Ridley-Jopling scale. Slit-skin smears for acidfast bacilli (AFB) were taken in all cases, and a skin biopsy to confirm the classification in about half of the patients. Voluntary muscle tests (VMT) were performed routinely for the nerves usually affected by leprosy.

In cases of facial nerve damage with lagophthalmos measurements were taken of the lid gap in millimetres during gentle and strong closure of the lids with a scale and this was repeated for evaluation of the effect of treatment with steroids.

\section{TREATMENT}

Treatment of recent facial nerve damage was with prednisolone. The usual initial dose of prednisolone was $25-30 \mathrm{mg}$ daily. This was normally reduced by $5 \mathrm{mg}$ daily per month. However the dosage was adjusted for bodyweight, and also for severity of neuritis (the more severe the neuritis the higher the initial steroid dosage, minimum $15 \mathrm{mg}$, maximum $40 \mathrm{mg}$ ). Patients were advised to take the prednisolone as a single morning dose. Treatment was unsupervised and on an outpatient basis.

1 However, if the reaction in the face persisted, or the lagophthalmos increased, the dosage was prolonged and/or temporarily increased to $30-40 \mathrm{mg} /$ day.

2 Patients were instructed to take the tablets regularly, and were warned that prednisolone was dangerous if not taken according to prescription.

3 In addition to the medical treatment the patient was advised to perform blinking exercises, about $5 \mathrm{~min}$ at a time, three times daily, trying to close the eyes, while looking in a mirror.

4 In case spontaneous blink was absent, patients were instructed to 'Think Blink' as suggested by Brandsma. ${ }^{4}$

5 Patients were encouraged to buy (sun) glasses for protection and relief. Glasses were supplied free of cost to patients who could not afford them.

\section{ASSESSMENTS DURING TREATMENT}

Patients were seen every 1-2 months during the period of steroid treatment, and every 2-6 months thereafter. Apart from routine examination, the gap of the eyelids was measured carefully in mm during gentle and strong closure. Patients were asked to demonstrate how 
they did their blinking exercises at home. The usefulness of protective glasses was emphasized.

In most patients the steroid dose was reduced monthly with the total duration of the course being 5-6 months. Usually the erythema in the face subsided and the lagophthalmos improved within the first few weeks.

\section{Results}

Between 1982 and 1988, 27 borderline patients (15 borderline-tuberculoid (BT), 2 borderline-borderline (BB), 10 borderline-lepromatous (BL)) were identified with recent facial nerve damage, who had completed a 6-month course of systemic steroids. Nearly all the patients had red and raised patches on the face at the side of the lagophthalmos at the time of registration. The facial nerve was bilaterally involved in 9 of these patients. All patients had a history of disease of less than 5 years and most patients had a history of lagophthalmos of less than 3 months duration. Sixteen patients had a follow-up of more than 6 months, after the end of the steroid course. A good end result was defined as complete closure of the eyelids on gentle closure of the eye. A satisfactory result was defined as a gap of $\leqslant 2 \mathrm{~mm}$ on gentle closure and $0 \mathrm{~mm}$ on strong closure. A poor result was considered a lid gap of $>2 \mathrm{~mm}$ on gentle closure, at the end of the course of steroids, regardless of improvement, compared to the initial lid gap. Of the 36 eyes involved, 27 $(75 \%)$ had complete closure or only a slight gap on gentle closure after treatment. Nine eyes $(25 \%)$ finished with a gap of more than $2 \mathrm{~mm}$ on gentle closure and were considered to be a poor result (Table 1). However, in most of these patients the lid gap had in fact diminished, compared to the initial assessment, either as a result of treatment with steroids or as a result of blinking exercises or both. Three eyes had a lid gap of $\geqslant 5 \mathrm{~mm}$ on gentle closure at the end of the course and were considered candidates for tarsoraphia. Table 1 shows clearly that the shorter the history of lagophthalmos, the better the result of steroid treatment. During follow-up 2 of the 27 patients $(1 \mathrm{BB}, 1 \mathrm{BL})$ had late recurrences of lagophthalmos, 2 years after an initial good result with complete closure of the lid gap, due to relapse and/or recurrent Type 1 reaction.

Table 1. Number of eyes and duration of lagophthalmos and end-result af ter treatment with steroids

\begin{tabular}{|c|c|c|c|c|}
\hline \multirow[b]{2}{*}{ Duration of lagophthalmos } & \multicolumn{3}{|c|}{ End result (no. of eyes) } & \multirow[b]{2}{*}{ Total } \\
\hline & Good* & Satisfactory $\dagger$ & Poor $\ddagger$ & \\
\hline $0-\leqslant 3$ months & $20 \S$ & 3 & 5 & 28 \\
\hline $4-\leqslant 6$ months & 1 & - & 2 & 3 \\
\hline$? ?$ & 2 & 1 & 2 & 5 \\
\hline Total & 23 & 4 & 9 & 36 \\
\hline \multicolumn{5}{|c|}{$\begin{array}{l}\text { * No gap on gentle closure. } \\
\text { † Gap on gentle closure } \leqslant 2 \mathrm{~mm} \text {. Gap on strong closure } 0 \mathrm{~mm} \text {. } \\
\text { ‡ Gap on gentle closure }>2 \mathrm{~mm} \text {. } \\
\S \text { Two patients initially had good results with complete closure of the lid } \\
\text { gap, but developed late recurrences after } 2 \text { years. }\end{array}$} \\
\hline
\end{tabular}




\section{Discussion}

As early as 1964, one study, ${ }^{5}$ mentioned the use of steroids in extensive tuberculoid lesions on the face in reaction especially when the lesions were in the neighbourhood of important nerves. It stated, 'It is important to begin corticosteroid therapy early in such cases, if irreversible facial palsy is to be averted.'

Although this is also a common experience among leprologists, no studies have been reported on the result of steroid treatment in lagophthalmos of recent onset. Treatment for lagophthalmos has usually concentrated on well established cases, focussing on physiotherapy, protective devices and surgery. ${ }^{6,7}$

Our results show that facial nerve damage, like early nerve damage elsewhere, can usually be reversed if treated well in time and for long enough. This will save the patient from a lifelong cosmetic blemish and constant watering and burning sensations of the eye, or, worse, from exposure keratitis, progressive corneal scarring and ultimate blindness. However, late recurrences in initially successfully treated patients may occur, as happened in 2 of our patients. Patients should be instructed to report immediately if such a recurrence appears.

Almost all our patients with recent lagophthalmos showed red and raised patches in the face, over the upper malar region or around the eye. Patients with impending or early lagophthalmos are therefore easy to recognize. This point needs to be stressed in the training courses and manuals of all field workers in leprosy.

Measurement of the lid gap in millimetres on gentle and strong closure was found to be a useful method, for initial assessment and follow-up. This method, being simple, can be easily practised by any field worker.

Steroids were found to be beneficial and safe for outpatient use in our lightweight patients, in the dosage we prescribed. In general, a steroid dosage of $60 \mathrm{mg}$ and over may be considered if patients can be hospitalized and monitored. ${ }^{8}$ Blinking exercises can reinforce the orbicularis muscle and thereby diminish the lid gap. We advocate a combination of the use of steroids, blinking exercises, and glasses for protection and comfort in patients with early lagophthalmos. This is in addition to the necessary antileprosy treatment.

\section{Conclusion}

Early detection of lagophthalmos is possible by being alerted by red and raised patches in the face, around the eye or in the malar area and by using simple methods, such as looking for a gap on gentle and strong closure. The measurement of this gap will also help in follow-up evaluation of treatment of facial nerve damage with lagophthalmos. A steroid regimen on an outpatient basis can give good results in most cases.

We hope that this paper will contribute towards defining a standard course of steroids for prevention or treatment of early lagophthalmos in the field.

\section{Acknowledgment}

Dhoolpet Leprosy Research Centre is managed by Victoria Hospital Dichpalli in collaboration with the Medical Research Council of Great Britain. 


\title{
References
}

1 Kiran KU, Stanley JNA, Pearson JMH. The out-patient treatment of nerve damage in patients with borderline leprosy, using a semi-standardized steroid regimen. Lepr Rev, 1985; 56: 127-34.

2 Touw-Langendijk Els MJ, Brandsma JW, Andersen JG. Treatment of ulnar and median nerve function loss in borderline leprosy. Lepr Rev, 1984; 55: 41-6.

${ }^{3}$ Hogeweg M, Kiran U, Suneetha S. The significance of facial patches in relation to recent facial nerve damage in leprosy. Lepr Rev; 62: 143-9.

${ }^{4}$ Brandsma JW. Blink-Bell-Blindness. Lepr Rev, 1984; 55: 421-8.

5 Browne SG. Corticosteroids in leprosy, a guide to their systematic use. Lepr Rev, 1964; 35: 157-63.

6 Brand Margaret E, ffytche TJ. Eye complications of leprosy. In: Leprosy. Hastings, (ed.), Medicines in the Tropics series. Edinburgh: Churchill Livingstone, 1985; pp. 223-42.

${ }^{7}$ Brand Margaret E. Care of the eye in Hansen's disease. Rev. 2nd. Ed. National Hansen's Disease Center, Carville, Louisiana, U.S.A., 1987.

8 Jacobson RR. Treatment. In: Leprosy. Hastings, (ed.), Medicines in the Tropics series. Edinburgh: Churchill Livingstone, 1985; pp. 193-222.

\section{Traitement de la dégradation récente du nerf facial avec lagophtalmie avec un régime de stéroïdes partiellement normalisé}

\author{
K Udaya Kiran, Margreet Hogeweg et Sujai Suneetha
}

Sommaire Vingt-sept patients (36 yeux) avec des cas limites de lèpre et détérioration du nerf facial (dont le commencement avait été moins de 6 mois avant) ont été mis, comme malades en consultation externe, sous un traitement composé d'un régime de stéroïdes partiellement normalisé (dose moyenne au début du régime de 25 à $30 \mathrm{mg}$; duration du régime de 5 à 6 mois). Les patients avec lagophtalmie récente montraient souvent des plaques réactives élevées et rouges dans la région malaire supérièure ou autour d'un œil ou des deux yeux.

L'espace entre les paupières a été mesuré en millimètres après fermeture légère ou serrée des yeaux. Après l'achèvement du régime de stéroïdes le $75 \%$ des yeux avaient récupéré la capacité de fermeture complète ou en laissant qu'un petit espace inférieur ou égal à $2 \mathrm{~mm}$ en fermant les yeux légérement.

Administrés dans les doses prescrites par nous, les stéroïdes se sont montrés bénéfiques et sans danger pour le patient.

\section{Tratamiento del nervio facial con deterioro reciente y lagoftalmía mediante un regimen de esteroides parcialmente normalizado}

\author{
K Udaya Kiran, Margreet Hogeweg y Sujai Suneetha
}

Resumen 27 pacientes ( 36 ojos) con casos límites de lepra y deterioro del nervio facial (habiendo comenzado el proceso de deterioro en los 6 meses anteriores) recibieron un régimen parcialmente normalizado de esteroides (la dosis media inicial siendo de 25 a $30 \mathrm{mg}$, administrada durante un periodo de 5 a 6 meses) como pacientes externos. Por regla general, los pacientes con lagoftalmía reciente mostraban placas elevadas y enrojecidas en la zona superior malar o alrededor de uno o de los dos ojos.

Se midió (en milímetros) el espacio entre los párpados al cerrar los ojos suave y fuertemente. Tras completar el tratamiento de esteroides se había recuperado la abilidad de cierre total, o dejando un espacio menor o igual a $2 \mathrm{~mm}$ al cerrarlos suavemente, en un $75 \%$ de los ojos.

Administrados en las dosis prescritas por nosotros, los esteroides resultaron tener efectos benéficos sin ser peligrosos para los pacientes. 